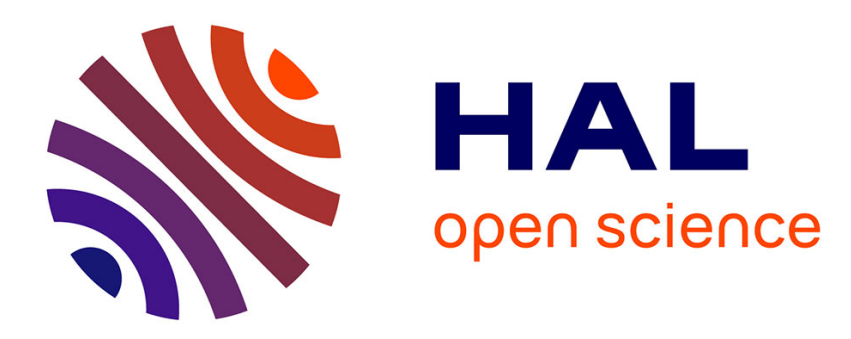

\title{
New aspects of rapid aldosterone signaling
}

\author{
C. Grossmann, M. Gekle
}

\section{To cite this version:}

C. Grossmann, M. Gekle. New aspects of rapid aldosterone signaling. Molecular and Cellular Endocrinology, 2009, 308 (1-2), pp.53. 10.1016/j.mce.2009.02.005 . hal-00499115

\section{HAL Id: hal-00499115 \\ https://hal.science/hal-00499115}

Submitted on 9 Jul 2010

HAL is a multi-disciplinary open access archive for the deposit and dissemination of scientific research documents, whether they are published or not. The documents may come from teaching and research institutions in France or abroad, or from public or private research centers.
L'archive ouverte pluridisciplinaire HAL, est destinée au dépôt et à la diffusion de documents scientifiques de niveau recherche, publiés ou non, émanant des établissements d'enseignement et de recherche français ou étrangers, des laboratoires publics ou privés. 


\section{Accepted Manuscript}

Title: New aspects of rapid aldosterone signaling

Authors: C. Grossmann, M. Gekle

PII:

DOI:

S0303-7207(09)00132-4

Reference: doi:10.1016/j.mce.2009.02.005

MCE 7146

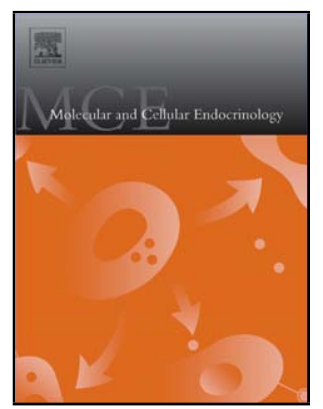

To appear in:

Molecular and Cellular Endocrinology

Received date:

9-9-2008

Revised date:

22-1-2009

Accepted date:

17-2-2009

Please cite this article as: Grossmann, C., Gekle, M., New aspects of rapid aldosterone signaling, Molecular and Cellular Endocrinology (2008), doi:10.1016/j.mce.2009.02.005

This is a PDF file of an unedited manuscript that has been accepted for publication. As a service to our customers we are providing this early version of the manuscript. The manuscript will undergo copyediting, typesetting, and review of the resulting proof before it is published in its final form. Please note that during the production process errors may be discovered which could affect the content, and all legal disclaimers that apply to the journal pertain. 


\section{New aspects of rapid aldosterone signaling}

C. Grossmann, M. Gekle

Julius-Bernstein-Institut für Physiologie, Universität Halle-Wittenberg, Halle/Saale, Germany

Address of correspondence:

Claudia Grossmann

Julius-Bernstein-Institut für Physiologie

Universität Halle-Wittenberg

Magdeburger Strasse 6, 06097 Halle/Saale

Germany

Tel.: ++49 3455571886

Fax: ++49 3455574019

e-mail: claudia.grossmann@medizin.uni-halle.de 
Aldosterone, the endogenous ligand of the mineralocorticoid receptor (MR) in humans, is a steroid hormone that regulates salt and water homeostasis. Recently, additional pathophysiological effects in the renocardiovascular system have been identified. Besides genomic effects mediated by activated MR, rapid aldosterone actions that are independent of translation and transcription have been documented. While these nongenomic actions influence electrolyte homeostasis, $\mathrm{pH}$ and cell volume in classical MR target organs, they also participate in pathophysiological effects in the renocardiovascular system causing endothelial dysfunction, inflammation and remodeling. The mechanisms conveying these rapid effects consist of a multitude of signaling molecules and include a cross-talk with genomic aldosterone effects as well as with angiotensin II and epidermal growth factor receptor signaling. Rapid corticosteroid signaling via the MR has also been demonstrated in the brain. Altogether, the function of nongenomic aldosterone effects seems to be to modulate other signaling cascades, depending on the surrounding milieu. 
Aldosterone, the endogenous mineralocorticoid in humans, was first isolated in 1953 as the last of the steroid hormones (Simpson et al., 1954). In the early years, the main focus of research lay on the long-term effects of aldosterone on sodium-potassium homeostasis and regulation of blood pressure in so called mineralocorticoid target organs like kidney, colon and salivary glands. These effects were reported to be "genomic", i.e. dependent on transcription and translation. It was discovered that aldosterone binds to the mineralocorticoid receptor (MR) in the cytoplasm, causing dissociation of chaperones and formation of MR dimers. These dimers then translocate into the nucleus and act as transcription factors to influence the expression of certain genes. Several genes were identified as being directly or indirectly regulated by aldosterone, for example $\mathrm{Na}^{+}-\mathrm{K}^{+}-\mathrm{ATPase}, \mathrm{ENaC}$ via SGK1 and ROMK, all of them concerned with electrolyte and volume regulation (Beesley et al., 1998; Chen et al., 1999; Kolla et al., 2000).

New interest in aldosterone arouse, when its effects in non-classical MC targets like VSMC, endothelial cells and cardiomyocytes were detected, showing an involvement in pathophysiological processes in the renocardiovascular system. Clinical studies demonstrated that patients with congestive heart failure or after myocardial infarction benefited from addition of MR antagonists to their treatment regiment (Pitt et al., 1999; Pitt et al., 2003a; Pitt et al., 2003b). Furthermore, the frequency of an elevated renin to aldosterone ratio in patients with hypertension was shown to be much higher than previously expected, leading to a reevaluation of the importance of aldosterone in patients with hypertension (Fardella et al., 2000; Rossi et al., 2006; Connell et al., 2003). In the search for the pathomechanism responsible for these positive effects of MR antagonists, the pathophysiological function of aldosterone in the renocardiovascular system came under fierce scrutiny. It was found that aldosterone participates in inflammatory and remodeling processes in these tissues, leading to fibrosis, endothelial dysfunction and hypertrophy (Blasi et al., 2003; Brilla et al., 1992; Qin et al., 2003; Rocha et al., 2002; Young et al., 2003). Because the mechanisms of action and additional conditions required were not clear, researchers began to look into the different signaling pathways of aldosterone in more depth. These include the rapid nongenomic effects, which do not require transcription or translation of genes. After long debates about their actual existence and biological relevance, discussions about their receptor and signaling pathways followed. Only recently, after the new interest in the pathophysiological effects of aldosterone and after acknowledging that there is a cross-talk between genomic and nongenomic effects have the possible consequences of rapid aldosterone signaling pathways come into focus.

\section{First evidence for nongenomic aldosterone signaling}

After long-time neglect of rapid aldosterone effects on sodium and potassium excretion in the kidney (Ganong et al., 1958), nongenomic effects of aldosterone were first postulated by Moura and Worcel in the mid 1980s (Moura et al., 1984). Early cellular studies demonstrated enhanced sodium exchange in canine erythrocytes, ruling out a genomic mechanism because of lack of a nucleus (SPACH et al., 1964). These studies were followed by investigations on aldosterone-mediated electrolyte transport in human mononuclear leukocytes (Wehling et al., 1989b; Christ et al., 1993; Wehling et al., 1990). A rapid increase in sodium-proton-exchange was detected which was declared nongenomic because of its rapid kinetics and insensitivity to inhibitors of translation or transcription (Wehling et al., 1989a). These early experiments explored aldosterone-dependent changes in second messenger systems without emphasis on the biological consequences. Nongenomic aldosteronemediated signaling events described included an elevation of intracellular $\mathrm{Ca}^{++}, \mathrm{IP3}, \mathrm{DAG}$ and PKC, PLC and cAMP (Christ et al., 1993; Christ et al., 1995b; Christ et al., 1999; Wehling et al., 1995; Wehling et al., 1996). Importantly, these effects were shown to occur not only in renal cells but also in VSMC and endothelial cells, i.e. cells of non-classical mineralocorticoid target organs (Christ et al., 1995a; Wehling et al., 1994; Wehling et al., 1995; Wehling et al., 1996). 
Much controversy arouse about the receptor conveying these effects. Early studies suggest that the nongenomic effects are mediated by a membrane receptor distinct from the classical cytoplasmic MR. Arguments supporting this concept include the rise in $\mathrm{Ca}^{++}$and cAMP found in cultured skin cells from MR knockout mice (Haseroth et al., 1999). Furthermore, antagonists against the classical MR like canrenone and spironolactone were not always able to inhibit the rapid effects of aldosterone (Good et al., 2002). In several studies, glucocortoicoids, which bind to the classical MR with an affinity comparable to that of aldosterone, could not elicit the same rapid effects as aldosterone (Doolan et al., 1996a). And last, aldosterone coupled to large molecules like BSA and therefore unable to cross the membrane rapidly, elicited the same rapid effects, favoring a membrane receptor (Le Moellic et al., 2004). Similar receptors have been proposed for other steroid hormones (Orshal et al., 2004; Zhu et al., 2003). However, there are several arguments against a structurally different MR responsible for nongenomic effects as well. Firstly, more flexible and water-soluble MR antagonists like RU28318 are able to inhibit the same nongenomic aldosterone effects that cannot be inhibited by spironolactone (Michea et al., 2005; Mihailidou et al., 2005). Secondly, Alzamora and collegues show in an elegant study that the lack of response to cortisol is due to $11 \beta-H S D$. $11 \beta-H S D$ is an enzyme co-localized with the MR which converts cortisol into the biologically inactive cortisone that is unable to bind to the MR. Inhibition of $11 \beta-H S D$ by carbenoxolone caused cortisol to exert similar rapid effects like aldosterone (Alzamora et al., 2000). And thirdly, in a heterologous expression system of HEK cells lacking classical MR, nongenomic effects involving ERK1/2 and JNK activation could only be induced after transient transfection with the classical MR. Cells lacking this receptor showed no rapid MAP kinase activation after incubation with aldosterone (Grossmann et al., 2005). Nevertheless, the same heterologous cell system revealed a rise in intracellular $\mathrm{Ca}^{++}$that is independent of the classical MR (Grossmann et al., 2005). Overall, the existence of nongenomically mediated aldosterone effects that seem to be mostly dependent on the classical MR and activate a variety of second messengers in both classical and nonclassical MR target organs was established in the early phase of rapid aldosterone research (Tab.1). These studies were followed by more in depth investigations on the signaling cascades involved and the pathophysiological effects conveyed.

\section{Nongenomic aldosterone effects in classical mineralocorticoid target organs}

In classical mineralocorticoid target organs like kidney and colon, a rapid effect of aldosterone on intracellular $\mathrm{pH}$ is detectable; a transient acidification is followed by a significant alkalization in both MDCK and M1 cells (Gekle et al., 1996; Markos et al., 2005; Wehling et al., 1996). There is much evidence that the rise in $\mathrm{pH}$ is caused by a rapid increase in intracellular $\mathrm{Ca}^{++}$followed by activation of the sodium-proton exchanger (NHE) (Doolan et al., 1996b; Oberleithner et al., 1987; Gekle et al., 2001; Markos et al., 2005). In MDCK cells, prerequisite for this process is a net entry of $\mathrm{Ca}^{++}$from outside the cell and a plasma membrane proton conductance to stimulate the NHE (Gekle et al., 1996). As source for the enhanced NHE activity, an increase in proton affinity was identified. When inhibiting NHE activity by a sodium free environment, proton conductance activation was unmasked and aldosterone induced a membrane potential-dependent acidification in MDCK and M1 cells. As shown by pharmacological studies, this process relies on PKC and heterotrimeric $\mathrm{G}$ proteins (Gekle et al., 1997). Furthermore, Harvey et al. demonstrated that aldosterone-induced activation of PKC $\alpha$ leads to a rapid increase in intracellular calcium through verapamil-sensitive ion channels, which then activates the NHE (Doolan et al., 1998; Harvey et al., 2002). The increase in $\mathrm{pH}$ then causes activation of a $\mathrm{pH}$ sensitive potassium channel $\mathrm{K}_{\mathrm{ATP}}$ and inhibition of $\mathrm{Ca}^{++}$-dependent $\mathrm{K}^{+}$-channels which lead to an increase in $\mathrm{K}^{+}$-recycling to maintain the electrical driving force for amiloride-sensitive $\mathrm{Na}^{+}-$ absorption while $\mathrm{Cl}^{-}$-secretion is inhibited (Maguire et al., 1999). Overall, the increase in intracellular sodium causes a change in cell volume that can be monitored by atomic force microscopy (Schneider et al., 1997b). These effects are insensitive to actinomycin D or cycloheximide. Further signaling 
molecules involved are the MAP kinases ERK1/2. Inhibitors of ERK1/2 phosphorylation are able to inhibit both the increase in intracellular $\mathrm{Ca}^{++}$and the activation of NHE. Preventing the increase in intracellular $\mathrm{Ca}^{++}$eliminates NHE stimulation but not ERK phosphorylation (Gekle et al., 2001). These results suggest that activation of NHE is mediated by an ERK-dependent increase in intracellular $\mathrm{Ca}^{++}$ in MDCK cells. Upstream of ERK1/2, aldosterone induces phosphorylation of the epidermal growth factor receptor (EGFR). Alternatively, PKC-induced activation of ERK1/2 followed by stimulation of NHE has also been demonstrated in other cell types (Markos et al., 2005). Several investigators identified c-src as the link between aldosterone-bound MR and MAP kinases often with EGFR as intermediate (Callera et al., 2005b; Grossmann et al., 2005; McEneaney et al., 2007). Activation of ERK1/2 was dependent on the classical MR but analogous to the progesterone and the estrogen receptor, deletion constructs containing only the MR domains E/F were sufficient (Grossmann et al., 2008). Additionally, involvement of heat shock protein 90 , the chaperone of the classical MR, has been reported (Braun et al., 2004; McEneaney et al., 2007). Besides regulating the ubiquitous basolateral NHE1, aldosterone also decreases apical NHE3 activity in the medullary thick ascending limb of the rat via an ERK1/2-dependent pathway, ultimately leading to a decrease in $\mathrm{HCO}^{-}$ reabsorption (Watts, III et al., 2006). The c-src -EGFR-signaling does not only lead to activation of MAP kinases but also seems to be a key element of another signaling pathway linking aldosterone to PKD1 activation in M1-CCD cells (McEneaney et al., 2007). To summarize, in classical mineralocorticoid target organs like kidney and colon, rapid effects of aldosterone are well characterized to lead to activation of PKC, intracellular calcium, EGFR and ERK1/2 and NHE with some evidence that the classical MR participates in at least some of these effects. Thereby, changes in $\mathrm{pH}$ and $\mathrm{Na}^{+}$are achieved, affecting cell volume and $\mathrm{pH}$ sensitive transporters like $\mathrm{K}_{\mathrm{ATP}}$ and $\mathrm{K}_{\text {са }}$ channels. Possible physiological consequences are regulation of cell volume independent of $\mathrm{pH}$ or membrane potential independent of sodium reabsorption.

\section{Nongenomic aldosterone effects in non-classical target tissues}

Aside from their effects on ion transport, aldosterone and the MR play an important role in cardiovascular diseases like indicated by three major clinical trials with MR antagonists and several smaller studies. The earliest trial, the RALES study, demonstrated an improvement in mortality and morbidity of patients with severe congestive heart failure after additional treatment with spironolactone (Pitt et al., 1999). A similar benefit could be detected after eplerenone in patients with left ventricular dysfunction after myocardial infarction (EPHESUS study) and in patients in the $4 \mathrm{E}$ study (Pitt et al., 2003a; Pitt et al., 2003b). Detailed investigations about the possible mechanisms leading to the advantageous effects of MR antagonists revealed an involvement of aldosterone in endothelial dysfunction, inflammation, remodeling processes and induction of hypertrophy and fibrosis (Leopold et al., 2007; Nagata et al., 2006; Guo et al., 2005; Rocha et al., 2002). At present, it is not clear which cell type(s), i.e. cardiac fibroblasts, cardiomyocytes or cells from vessels (VSMC, endothelium) is/are primarily responsible for these deleterious effects. Although it seems clear that genomic effects are involved in the pathophysiological effects of aldosterone outlined above, a contribution of rapid nongenomic effects to support them is also likely.

Especially a role in furthering endothelial dysfunction which then triggers a cascade of pathophysiological mechanisms leading to aldosterone's pathophysiological effects has been discussed (Tab.2). Overall, with invasive and noninvasive techniques, aldosterone causes a vasoconstriction of resistance arteries with an increase in systemic peripheral resistance and a reduction in cardiac output (Klein et al., 1964; Schmidt et al., 1999; Wehling et al., 1998). Accordingly, the forearm blood flow was reduced after local intra-arterial application of aldosterone both in healthy volunteers and patients with stabile chronic heart failure (Gunaruwan et al., 2005; Romagni et al., 2003). However, opposite effects and no effects of aldosterone per se have also been reported (Klein et al., 1964; Nietlispach et al., 2007). Reconciling these adverse results, Schmidt et al. 
showed that the effects of aldosterone depend on the adrenergic state of the individuals and their health status, which influences the equilibrium of endothelium versus vascular smooth muscle cell action (Schmidt et al., 2006; Schmidt et al., 2001; Schmidt et al., 2003). While aldosterone enhances the NO release of the endothelium, it also causes contraction of the smooth muscle cells underneath (Schmidt et al., 2006; Schmidt et al., 2003). Therefore, in a state of endothelial dysfunction, aldosterone is likely to cause further increase in resistance, thereby mediating arterial hypertension (Schmidt et al., 2006). Experimentally, this thesis was tested by applying aldosterone to intact and endothelium-denuded aortic rings. As a result, attenuation of phenylephrine-mediated vasoconstriction caused by aldosterone via enhanced NO synthase activity in intact aortic rings could be reversed into a vasoconstriction mediated by smooth muscle cells in endothelium-denuded aortic rings (Liu et al., 2003). In endothelial cells, one possible mechanism for the enhanced NO production is an PI3 kinase and PKB/Akt-mediated stimulation of eNOS possibly by synergizing calciumdependent eNOS phosphorylation at Ser 1179 (Mutoh et al., 2008). Another study demonstrated that inhibition of NO synthase plus aldosterone causes an increase in GFR and a fall in RPF in healthy volunteers (Schmidt et al., 2006). Likewise the inhibitory action of aldosterone on depolarizationmediated vasoconstriction in renal afferent arterioles could be mimicked by the NO donor sodium nitroprussid (Uhrenholt et al., 2003). Aldosterone-induced contraction of smooth muscle cells was investigated further and found to be mediated by PLC, intracellular $\mathrm{Ca}^{++}$, PKC and the IP3 pathway (Arima et al., 2003; Arima et al., 2004). Paralleled by a dose-dependent contraction of VSMC, a PI3 kinase-mediated enhanced phosphorylation of the myosin light chain was detected, which could lead to a vasoconstriction in preexisting endothelial dysfunction (Gros et al., 2007). Furthermore, in rabbit renal arterioles, the dose-dependent vasoconstriction caused by aldosterone in the afferent and efferent arteriole seems to depend on L-type VDCC in case of the afferent arteriole and on T-type VDCC in the case of the efferent arteriole (Arima et al., 2003). Because the ex vivo effects could be inhibited by spironolactone, an involvement of the classical MR in these rapid effects of the vasculature is suggested (Liu et al., 2003; Uhrenholt et al., 2003; Gros et al., 2007). Overall, these results indicate that aldosterone influences the vascular tone via the classical MR depending on the balance between endothelial NO release and vascular smooth muscle cell contraction and therefore depending on the health status and the surrounding milieu.

Recently, special emphasis has been laid on the balance between aldosterone's ability to produce NO and to activate reactive oxygen species (ROS) in the endothelium (Skott et al., 2006). On the one hand, aldosterone is able to induce production of NO by eNOS in endothelium (Liu et al., 2003; Mutoh et al., 2008). Under conditions of low oxygen tension and $\mathrm{NaCl}$ diet this leads to a vasodilation. On the other hand, aldosterone also stimulates the NADPH oxidase via c-src leading to increased ROS generation (Iwashima et al., 2008). The generation of ROS is especially marked under conditions of high oxygen tension, high $\mathrm{NaCl}$ diet or inflammation, producing superoxide and together with NO peroxynitrite (Beckman et al., 1990; Beckman et al., 1996). Under such circumstances, NO concentrations are not only reduced by peroxynitrite formation but also by uncoupling of eNOS through oxidation of tetrahydrobiopterin (Kuzkaya et al., 2003). Aldosterone promotes the uncoupling of NOS further by activating PP2A and thereby causing dephosphorylation of Ser1177 (Nagata et al., 2006). Additionally, aldosterone decreases the expression of glucose-6phosphate dehydrogenase and thereby limits the amount of NADPH available for scavenging oxygen radicals (Leopold et al., 2007). In conclusion, in an unstressed situation, aldosterone would lead to production of $\mathrm{NO}$ and vasodilation together with a low production of superoxide that would be mostly transformed to $\mathrm{H}_{2} \mathrm{O}_{2}$ and small amounts of peroxynitrite. With increased stress, activation of NADPH oxidase, inhibition of glucose-6-phosphate dehydrogenase and uncoupling of NOS will lead to an increase in superoxide, $\mathrm{H}_{2} \mathrm{O}_{2}$, and peroxynitrite that can cause oxidative damage and vasoconstriction as well as activation of platelets because of low NO concentrations (Skott et al., 2006). 
A rapid aldosterone-induced activation of NADPH oxidase with consecutive enhanced production of ROS has been further reported in VSMC, rat neonatal myocytes and mesangial cells. In cardiomyocytes, as a consequence of enhanced ROS formation, apoptosis has been described as well as activation of MMP-2 and MMP-9 with the possible induction of remodeling processes (Hayashi et al., 2008; Rude et al., 2005). Rapid activation of the NADPH oxidase depended on ERK1/2 phosphorylation and PKC and most likely involves enhanced membrane translocation of p47phox and p67phox as suggested by Miyata et al. (Miyata et al., 2005). The constant RNA levels found for NOX2 in cardiomyocytes support this hypothesis (Hayashi et al., 2008). Furthermore, c-src has also been accused of activating NADPH oxidase in VSMC. For c-src a rapid aldosterone-mediated activation of p38 which causes enhanced proline incorporation has been reported, indicating enhanced collagen synthesis and profibrotic actions. An upregulation of this pathway with increased c-src phosphorylation, NADPH oxidase activity and collagen synthesis could be found in vascular myocytes from spontaneously hypertensive rats and was sensitive to inhibition by eplerenone (Callera et al., 2005a). Because some genomic pathophysiological aldosterone effects are dependent on the coexistence of additional stressors like ROS, nongenomic ROS production could have a profound influence on the overall pathophysiological processes induced by aldosterone (Gekle et al., 2007).

An additional pathophysiological mechanism described for aldosterone is the induction of inflammation which then leads to remodeling processes including fibrosis and hypertrophy. Recent studies indicate that mineralocorticoid-induced NHE activation in vascular smooth muscle cells is involved in such inflammatory processes, measured as an increase in ED-1 and osteopontin. In the same study, enhanced collagen deposition was also detected, which could be inhibited by canrenoate or the NHE blocker cariporide (Young et al., 2003). Additionally, inhibition of NHE1 was able to prevent DOCA / salt-induced MR-mediated cardiac hypertrophy (Fujisawa et al., 2003). The mechanisms for this augmented NHE activity include an increase in $\mathrm{Na}^{+}$sensitivity but also an increase in NHE expression via enhanced translocation to the membrane and stimulation of de-novo synthesis (Ebata et al., 1999). Like demonstrated for classical MR target organs, the $\mathrm{Na}^{+} / \mathrm{H}^{+}$exchange can therefore be nongenomically activated but it also possesses a prolonged component which is attributed to genomic actions (Miyata $Y$ et al., 2005; Ebata et al., 1999). Taken together, the pathophysiological effects leading to inflammation and remodeling seem to involve classical MR and are mediated by a combination of nongenomic and genomic effects which interact with one another.

A further aldosterone-dependent pathway leading to cardiac remodeling with emphasis on hypertrophy is inhibition of the $\mathrm{Na}^{+}-\mathrm{K}^{+}$ATPase (Kometiani et al., 1998). In a series of patch clamp studies involving rabbit cardiomyocytes, aldosterone caused a decrease in $\mathrm{Na}^{+}-\mathrm{K}^{+}$pump activity and an increase in intracellular sodium activity after 7 days of treatment. This effect on the pump could be inhibited by losartan or MR inhibitors (Mihailidou et al., 2000; Mihailidou et al., 2002). Additionally, a rapid increase in $\mathrm{Na}^{+}-\mathrm{K}^{+}-2 \mathrm{Cl}^{-}$cotransporter activity was found, leading to an increase in intracellular sodium with increase in $\mathrm{Na}^{+}-\mathrm{K}^{+}$ATPase activity. When inhibiting the $\mathrm{Na}^{+}-\mathrm{K}^{+}-2 \mathrm{Cl}^{-}$ cotransporter, a decreased $\mathrm{Na}^{+}-\mathrm{K}^{+}$ATPase activity could be unmasked that was mediated by PKCE. Interestingly, the long-lived and prolonged inhibitory effect of aldosterone on the pump could be inhibited acutely by inhibition of $\mathrm{PKC} \varepsilon$, again suggesting that genomic and nongenomic effects are intertwined (Mihailidou et al., 1998; Mihailidou, 2006). Besides having direct effects on cardiomyocytes, aldosterone can also indirectly enhance cardiac remodeling by reducing compensatory mechanisms in response to stressors. For example, the intracoronary administration of aldosterone rapidly decreased coronary blood flow along with fractional shortening and lactate extraction rate. This decrease in coronary blood flow was reproduced by the infusion of bovine serum albumin-conjugated aldosterone and blunted by co-administration of a PKC inhibitor, indicating that aldosterone nongenomically induces vasoconstriction via a PKC-dependent pathway. In case of ischemia, this mechanism leads to a worsening of the cardiac contractile and metabolic 
functions and therefore to an increase in cardiac damage (Fujita et al., 2005). Thus, aldosterone can augment cardiac remodeling through direct effects on the cardiomyocytes transporters but also through indirect effects that decrease the hearts ability to cope with injuries. Paradoxically, conditional overexpression of MR in cardiomyocytes causes arrhythmias but does not induce structural alterations in the heart while partial knock-down of the MR results in severe cardiac failure and fibrosis (Beggah et al., 2002; Ouvrard-Pascaud et al., 2005).

\section{Interaction between nongenomic and genomic}

As demonstrated above, there are indications for an interaction between nongenomic and genomic aldosterone signaling throughout literature with a tendency that nongenomic effects enhance or support genomic effects. For instance, by measuring the genomic response to aldosterone with and without inhibiting rapid ERK1/2 activation, one finds that nongenomic ERK activation enhances genomic aldosterone responses at a glucocorticoid response element. As a possible mechanism for this interaction an induction of the nuclear-cytoplasmic shuttling was identified (Grossmann et al., 2005). Interestingly, this interaction between nongenomic and genomic aldosterone effects is dependent on the $n$-terminal domain of the MR; deletion constructs without $A / B$ domain do not respond to inhibition of the rapid ERK1/2 signaling. Furthermore, inhibiting the early aldosteroneinduced PKC $\alpha$ pathway results in reduced MR transactivation activity and short-circuit current (Le Moellic et al., 2004). A rapid aldosterone- and PKC $\alpha$-mediated phosphorylation and thereby activation of the MR was demonstrated as the underlying mechanism. Several reports indicate synergistic effects of nongenomic and genomic aldosterone actions. For example, activation of NHE that induces pathophysiological effects like vasoconstriction, cardiac fibrosis and hypertrophy (Fujisawa et al., 2003; Michea et al., 2005; Young et al., 2003) is regulated nongenomically and genomically by aldosterone and PKC in VSMC (Ebata et al., 1999; Miyata Y et al., 2005). Moreover, some of the nongenomic effects begin rapidly but continue as prolonged effects like indicated by the long-lived effect of aldosterone on the $\mathrm{Na}^{+}-\mathrm{K}^{+}$-ATPase that could be rapidly reversed by PKCE inhibition within $15 \mathrm{~min}$ (Mihailidou et al., 2004a). Other indications for the importance of nongenomic effects for long lasting effects come from in vivo studies that suggest that nongenomic aldosterone effects lead to an increase in renal vascular resistance with a decrease in GFR and an increase in RPF in humans with impaired endothelial function (Schmidt et al., 2006). Consequently, nongenomic aldosterone signaling can lead to long-lasting effects either by being prolonged itself or by interacting with genomic effects. Another intriguing finding is that aldosterone exerts nongenomic effects on the same ion transporters that it also regulates genomically. A possible mechanism for the nongenomic aldosterone effects is an interaction with the cytoskeleton and thereby with the trafficking of ion transporters. For example, aldosterone rapidly activates the NHE in VSMC, a process that can be blocked by inhibitors of microtubule polymerization and filamentous actin formation (Ebata et al., 1999). A similar effect of aldosterone on the cytoskeleton has been documented for the epithelial sodium channel ENaC. McEneamy et al. showed that aldosterone nongenomically influenced the trafficking of this channel (McEneaney et al., 2008). Additionally, ENaC activation could be inhibited by colchicine and cytochalasin D (Golestaneh et al., 2001). A similar inhibitory effect of colchicine on the nongenomic aldosterone actions has also been described for the sodiumpotassium-pump although in this case the nongenomic actions antagonized the genomic effect (Alzamora et al., 2003). Taken together, there are various interactions between nongenomic and genomic aldosterone effects including direct facilitation of genomic signal transduction through nongenomic signaling and synergistic effects of both mechanisms of action on certain target molecules. The demonstration of prolonged nongenomic aldosterone effects highlights their relevance for overall aldosterone actions but also renders the distinction between genomic and nongenomic signaling more difficult. 


\section{Interaction with other signaling molecules: angiotensin II, EGFR}

However, there is not only a cross-talk between nongenomic and genomic pathways of aldosterone but also with other pathophysiologically relevant signaling cascades of the renocardiovascular system. One of these signaling partners is angiotensin II (angII) which classically binds to the Gprotein-coupled AT1 receptor, thereby leading to aldosterone secretion from the adrenals. Joint actions between MR and angll have been described in cells that are incapable of secreting aldosterone. For instance, in aortic rings from Sprague-Dawley rats and in human coronary arteries, aldosterone enhanced angll-stimulated contractions (Chai et al., 2005; Ullian et al., 1996). Early observations demonstrate further that angll-induced incorporation of ${ }^{3}[\mathrm{H}]$-thymidine in rat aortic smooth muscle cells can be inhibited by spironolactone and that aldosterone is required for full proliferative response to angll. In neither case, aldosterone had an effect per se. One suggested interaction was a modulation of AT1 receptor expression (Xiao et al., 2000; Xiao et al., 2004). Experiments in human coronary smooth muscle cells, however, reveal that angll via the AT1R enhances translocation of the MR into the nucleus with resulting alterations in gene expression, suggesting a transactivation of the MR via the AT1R (Jaffe et al., 2005). While these effects are not necessarily nongenomic, Mazak et al. showed that aldosterone and angll lead to a potentiation of rapid ERK1/2 and JNK phosphorylation in VSMC of double transgenic human renin and angiotensin rats that could not be inhibited by actinomycin $D$ or cycloheximide. MR blockade reduced ERK1/2 phosphorylation and attenuated angll-induced end-organ damage in vivo (Mazak et al., 2004). This observation was carried further by Min et al., who found that aldosterone and angll synergistically induce an ERK-dependent mitogenic response in VSMC measured as enhanced DNA synthesis (Mazak et al., 2004; Min et al., 2005). This effect was attributed to aldosterone actions mediated by nongenomic and genomic mechanisms.

Phosphorylation of ERK1/2 is one of the best documented signaling steps of nongenomic aldosterone actions (Gekle et al., 2001; Mazak et al., 2004; McEneaney et al., 2007; Rossol-Haseroth et al., 2004). Besides being part of a cascade that includes upstream activation of PKC, ERK1/2 is also part of epidermal growth factor receptor (EGFR) signaling (Grossmann et al., 2005; Markos et al., 2005). The EGFR is a growth factor receptor known for its induction of cell proliferation and remodeling processes in the renocardiovascular system (Francois et al., 2004; Kagiyama et al., 2003; Terzi et al., 2000) and it is also responsible for at least part of the pathophysiological effects induced by angll and endothelin-1 in these tissues (Bokemeyer et al., 2000; Flamant et al., 2003; Kagiyama et al., 2002; Zhai et al., 2006). Several reports exist about an interaction between aldosterone and the EGFR. They include a spironolactone-induced decrease in EGFR mRNA and protein that coincides with a decrease in cerebral vascular remodeling and infarct size or a decrease in perivascular fibrosis in coronary arteries (Dorrance et al., 2001; Dorrance et al., 2006; Nakano et al., 2005). Additionally, an increase in EGFR mRNA and an upregulation of arterial contraction to epidermal growth factor was elicited by aldosterone (Florian et al., 2001). While aldosterone-bound MR enhances EGFR promoter activity and consequently EGFR expression, transactivation of the EGFR has also been found (Grossmann et al., 2007; Grossmann et al., 2005). As a bridge molecule between aldosterone-activated MR and transactivation of the EGFR c-src was identified (Grossmann et al., 2005; McEneaney et al., 2007). Interestingly, overexpression of MR without steroids also leads to ligand-independent ERK1/2 activation (Grossmann et al., 2008). One consequence of rapid aldosterone actions is a sensitization of cells for EGF with a leftward shift of the dose-response curve in the presence of the EGFR (Krug et al., 2002). Furthermore, through the EGFR pathway, $\mathrm{Na}^{+}-\mathrm{H}^{+}$-exchanger activity is stimulated and PKD activated (Gekle et al., 2002; McEneaney et al., 2008), which eventually results in ENaC subunit intracellular trafficking affecting sodium content of cells and proliferation of cardiomyocytes. Nongenomic aldosterone effects also contribute to proliferation of vascular smooth muscle cells via phosphorylation of the EGFR (Min et al., 2005). Together with angll, aldosterone leads to a rapid and 
sustained ERK phosphorylation mediated by EGFR transactivation which then leads to changes in gene expression of ki-ras2A and downregulation of the phosphatase MkP-1 which is responsible for proliferation of VSMC. Additionally, stimulation of cardiac fibroblast proliferation has also been associated with ki-rasA induction (Stockand et al., 2003). To decipher between prolonged nongenomic and genomic effects, deletion constructs of the MR without DNA-binding domain were tested for their effect on collagen III secretion. Even without DNA-binding domain, aldosteroneinduced MR furthered $\mathrm{H}_{2} \mathrm{O}_{2}$-stimulated increase in collagen III secretion. This seems to be a prolonged nongenomic effect involving EGFR, highlighting that nongenomic aldosterone effects can have long-lasting results with pathophysiological relevance (Grossmann et al., 2008; Mihailidou et al., 2004b). Overall, the EGFR is an important signaling component that appears in genomic and nongenomic signaling of aldosterone and takes part in the cross-talk between both ways of communication.

\section{Nongenomic corticosteroid effects in the brain}

Another non-classical target tissue involved in rapid mineralocorticoid receptor effects is the brain. While some parts of the CNS that regulate salt appetite have access to aldosterone and possess $11 \beta$ HSD to ensure MR specificity, most parts of the brain possess MRs without specificity. Importantly, in these areas glucocorticoids possess two signaling pathways either via the high affinity MR or the lower affinity GR. Rapid corticosteroid effects have been described on feedback operation in the HPA axis (Dallman, 2005), in appraisal of novel situations and retrieval processes (Di et al., 2003; Oitzl et al., 1994). For example, a rapid and therefore nongenomic negative feedback control of corticosterone on the production and release of CRH was demonstrated. As a possible mechanism, corticosterone was shown to decrease the release probability of glutamate-containing vesicles in the paraventricular nucleus ( $\mathrm{Di}$ et al., 2003). This presynaptic process was dependent on a postsynaptic G-protein linked pathway (Malcher-Lopes et al., 2006). Furthermore, endocannaboinoid synthesis and signaling via a presynaptic CB1 receptor were suggested to be involved (Di et al., 2003). Neither classical MR nor GR seem to mediate this effect.

Especially high levels of MR expression are located in limbic areas, mainly the hippocampus. Rapid effects of aldosterone on the hippocampus include facilitation of the release of glutamate containing vesicles thus enhancing miniature excitatory postsynaptic currents in CA1 neurons via a presynaptic ERK1/2 pathway (Olijslagers et al., 2008). This effect can be blocked by spironolactone and is not present in forebrain-specific MR knockout mice receiving corticosterone (Karst et al., 2005). Additionally, a decrease in $\mathrm{K}^{+}$-conductance IA via postsynaptic G-protein-coupled MRs was found, possibly increasing the likelihood of a postsynaptic action potential further (Olijslagers et al., 2008). One consequence could be the facilitation of long-term potentiation which has been described as a long-term effect of activated MR (Avital et al., 2006; Berger et al., 2006). Furthermore, a rapid effect of corticosterone in facilitating long-term potentiation of beta-adrenergic agonists has been described as well as a rapid MAP kinase- and MR-dependent maintenance of long-term potentiation by swim stress in the dentate gyrus (Ahmed et al., 2006; Korz et al., 2003; Pu et al., 2007). Overall, speculations have been made by de Kloet et al that the permissive effects of corticosterone, partly mediated by MR, may further rapid encoding of stress-related information and selecting of appropriate behavioral responses for coping (de Kloet et al., 2008). On the other hand, there are also reports about a nongenomic blockade of memory retrieval by activated MR (Khaksari et al., 2007). Overall, the function of the MR in the CNS is complex and needs to be elucidated further.

In summary, nongenomic aldosterone signaling consists of an intricate network of signaling cascades that often involve the classical MR (Fig. 1). In classical MC target organs like kidney and colon, rapid effects of aldosterone have been demonstrated to influence electrolyte homeostasis, $\mathrm{pH}$ and cell volume. Additionally, pathophysiological effects including inflammation, remodeling processes and endothelial dysfunction have been described that have been especially well documented in cells of 
the renocardiovascular system. Nongenomic aldosterone actions support these effects by modulating vascular tone, ROS production, remodeling processes and proliferation of cells, making tissues more vulnerable to additional stress. As mechanisms of action, a combination of nongenomic and genomic effects that interact with one another have been identified. However, aldosterone not only possesses a cross-talk between its own signaling pathways but it also modulates the signaling pathways of other pathophysiologically relevant molecules like angll and the epidermal growth factor receptor (EGFR). Corticosteroids in the brain also exert nongenomic effects and are involved in neuronal function and stress response via the MR.

Work from the authors was funded by the Deutsche Forschungsgesellschaft (DFG) and ESAC Deutschland. 
Fig. 1

Overview over the different pathways and effects of aldosterone signaling. 
1. Ahmed,T., Frey,J.U., and Korz,V., 2006. Long-Term Effects of Brief Acute Stress on Cellular Signaling and Hippocampal LTP. J. Neurosci. 26,3951-3958.

2. Alzamora,R., Michea,L., and Marusic,E.T., 2000. Role of 11 beta-hydroxysteroid dehydrogenase in nongenomic aldosterone effects in human arteries. Hypertension 35,1099-1104.

3. Alzamora,R., Brown,L.R., and Harvey,B.J., 2007. Direct Binding and Activation of Protein Kinase $\mathrm{C}$ Isoforms by Aldosterone and 17\{beta\}-Estradiol. Molecular Endocrinology 21,2637-2650.

4. Alzamora,R., Marusic,E.T., Gonzalez,M., and Michea,L., 2003. Nongenomic Effect of Aldosterone on $\mathrm{Na}+, \mathrm{K}+-$ Adenosine Triphosphatase in Arterial Vessels. Endocrinology $144,1266-1272$.

5. Arima,S., Kohagura,K., Xu,H.L., Sugawara,A., Abe,T., Satoh,F., Takeuchi,K., and Ito,S., 2003. Nongenomic vascular action of aldosterone in the glomerular microcirculation. J Am Soc Nephrol 14,2255-2263.

6. Arima,S., Kohagura,K., Xu,H.L., Sugawara,A., Uruno,A., Satoh,F., Takeuchi,K., and Ito,S., 2004. Endothelium-derived nitric oxide modulates vascular action of aldosterone in renal arteriole. Hypertension 43,352-357.

7. Avital,A., Segal,M., and Richter-Levin,G., 2006. Contrasting Roles of Corticosteroid Receptors in Hippocampal Plasticity. J. Neurosci. 26,9130-9134.

8. Barbato,J.C., Mulrow,P.J., Shapiro,J.I., and Franco-Saenz,R., 2002. Rapid effects of aldosterone and spironolactone in the isolated working rat heart. Hypertension 40,130-135.

9. Beckman,J.S., Beckman,T.W., Chen,J., Marshall,P., and Freeman,B.A., 1990. Apparent hydroxyl radical production by peroxynitrite: implications for endothelial injury from nitric oxide and superoxide. Proc Natl Acad Sci U S A 87,1620-1624.

10. Beckman,J.S. and Koppenol,W.H., 1996. Nitric oxide, superoxide, and peroxynitrite: the good, the bad, and ugly. AJP - Cell Physiology 271,C1424-C1437.

11. Beesley,A.H., Hornby,D., and White,S.J., 1998. Regulation of distal nephron K+ channels (ROMK) mRNA expression by aldosterone in rat kidney. J Physiol (Lond) 509,629-634.

12. Beggah,A.T., Escoubet,B., Puttini,S., Cailmail,S., Delage,V., Ouvrard-Pascaud,A., Bocchi,B., Peuchmaur,M., Delcayre,C., Farman,N. et al, 2002. Reversible cardiac fibrosis and heart failure induced by conditional expression of an antisense mRNA of the mineralocorticoid receptor in cardiomyocytes. Proc Natl Acad Sci U S A 99,71607165 .

13. Berger,S., Wolfer,D.P., Selbach,O., Alter,H., Erdmann,G., Reichardt,H.M., Chepkova,A.N., Welzl,H., Haas,H.L., Lipp,H.P. et al, 2006. Loss of the limbic mineralocorticoid receptor impairs behavioral plasticity. Proc. Natl. Acad. Sci. U. S. A 103,195-200. 
14. Blasi,E.R., Rocha,R., Rudolph,A.E., Blomme,E.A., Polly,M.L., and McMahon,E.G., 2003. Aldosterone/salt induces renal inflammation and fibrosis in hypertensive rats. Kidney Int 63,1791-1800.

15. Blazer-Yost,B.L., Helman,S.I., Lee,K.D., and Vlahos,C.J., 1999. Phosphoinositide 3kinase is required for aldosterone-regulated sodium reabsorption. AJP - Cell Physiology 277,C531-C536.

16. Bokemeyer,D., Schmitz,U., and Kramer,H.J., 2000. Angiotensin II-induced growth of vascular smooth muscle cells requires an Src-dependent activation of the epidermal growth factor receptor. Kidney Int. 58,549-558.

17. Bowley,K.A., Linley,J.E., Robins,G.G., Kopanati,S., Hunter,M., and Sandle,G.I., 2007. Role of protein kinase $C$ in aldosterone-induced non-genomic inhibition of basolateral potassium channels in human colonic crypts. The Journal of Steroid Biochemistry and Molecular Biology 104,45-52.

18. Braun,S., Lösel,R.M., Wehling,M., and Boldyreff,B., 2004. Aldosterone rapidly activates Src kinase in M-1 cells involving the mineralocorticoid receptor and HSP84. FEBS Lett 570,69-72.

19. Brilla,C.G. and Weber,K.T., 1992. Mineralocorticoid excess, dietary sodium, and myocardial fibrosis. J Lab Clin. Med. 120,893-901.

20. Callera,G.E., Montezano,A.C.I., Yogi,A., Tostes,R.C., He,Y., Schiffrin,E.L., and Touyz,R.M., 2005a. c-Src-Dependent Nongenomic Signaling Responses to Aldosterone Are Increased in Vascular Myocytes From Spontaneously Hypertensive Rats. Hypertension 46,1032-1038.

21. Callera,G.E., Touyz,R.M., Tostes,R.C., Yogi,A., He,Y., Malkinson,S., and Schiffrin,E.L., 2005b. Aldosterone Activates Vascular p38MAP Kinase and NADPH Oxidase Via c-Src. Hypertension 45,773-779.

22. Chai,W., Garrelds,I.M., Vries,R.d., Batenburg,W.W., van Kats,J.P., and Danser,A.H.J., 2005. Nongenomic Effects of Aldosterone in the Human Heart. Interaction With Angiotensin II. Hypertension 46,701-706.

23. Chen,S.-Y., Bhargava,A., Mastroberardino,L., Meijer,O.C., Wang,J., Buse,P., Firestone,G.L., Verrey,F., and Pearce,D., 1999. Epithelial sodium channel regulated by aldosterone-induced protein sgk. Proc. Natl. Acad. Sci. USA 96,2514-2519.

24. Christ,M., Douwes,K., Eisen,C., Bechtner,G., Theisen,K., and Wehling,M., 1995a. Rapid effects of aldosterone on sodium transport in vascular smooth muscle cells. Hypertension 25,117-123.

25. Christ,M., Eisen,C., Aktas,J., Theisen,K., and Wehling,M., 1993. The inositol-1,4,5trisphosphate system is involved in rapid effects of aldosterone in human mononuclear leukocytes. J. Clin. Endocr. Metab. 77,1452-1457.

26. Christ,M., Günther,A., Heck,M., Schmidt,B.M.W., Falkenstein,E., and Wehling,M., 1999. Aldosterone, Not Estradiol, Is the Physiological Agonist for Rapid Increases in cAMP in Vascular Smooth Muscle Cells. Circulation 99,1485-1491. 
27. Christ,M., Meyer,C., Sippel,K., and Wehling,M., 1995b. Rapid aldosterone signaling in vascular smooth muscle cells: involvement of phospholipase $\mathrm{C}$, diacylglycerol and protein kinase $\mathrm{C} \alpha$. Biochem. Biophys. Res. Commun. 213,123-129.

28. Connell,J.M.C., Fraser,R., MacKenzie,S., and Davies,E., 2003. Is Altered Adrenal Steroid Biosynthesis a Key Intermediate Phenotype in Hypertension? Hypertension 41,993-999.

29. Dallman,M.F., 2005. Fast glucocorticoid actions on brain: Back to the future. Frontiers in Neuroendocrinology 26,103-108.

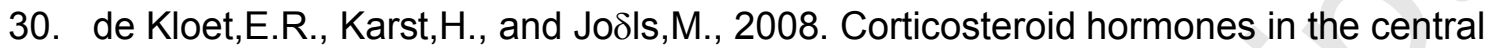
stress response: Quick-and-slow. Frontiers in Neuroendocrinology 29,268-272.

31. Di Zhang,A., Cat,A.N.D., Soukaseum,C., Escoubet,B., Cherfa,A., Messaoudi,S., Delcayre,C., Samuel,J.L., and Jaisser,F., 2008. Cross-Talk Between

Mineralocorticoid and Angiotensin II Signaling for Cardiac Remodeling. Hypertension 52,1060-1067.

32. Di,S., Malcher-Lopes,R., Halmos,K.C., and Tasker,J.G., 2003. Nongenomic Glucocorticoid Inhibition via Endocannabinoid Release in the Hypothalamus: A Fast Feedback Mechanism. J. Neurosci. 23,4850-4857.

33. Doolan,C.M. and Harvey,B.J., 1996a. Modulation of cytosolic protein kinase C and calcium ion activity by steroid hormones in rat distal colon. J. Biol. Chem. 271,87638767.

34. Doolan,C.M. and Harvey,B.J., 1996b. Rapid effects of steroid hormones on free intracellular calcium in T84 colonic epithelial cells. Am. J. Physiol. 271,C1935-C1941.

35. Doolan,C.M., O'Sullivan,G.C., and Harvey,B.J., 1998. Rapid effects of corticosteroids on cytosolic protein kinase $\mathrm{C}$ and intracellular calcium concentration in human distal colon. Mol Cell Endocrinol 138,71-79.

36. Dorrance,A.M., Osborn,H.L., Grekin,R., and Webb,R.C., 2001. Spironolactone reduces cerebral infarct size and EGF-receptor mRNA in stroke-prone rats. Am J Physiol Regul Integr Comp Physiol 281,R944-R950.

37. Dorrance,A.M., Rupp,N.C., and Nogueira,E.F., 2006. Mineralocorticoid Receptor Activation Causes Cerebral Vessel Remodeling and Exacerbates the Damage Caused by Cerebral Ischemia. Hypertension 47,590-595.

38. Ebata,S., Muto,S., Okada,K., Nemoto,J., Amemiya,M., Saito,T., and Asano,Y., 1999. Aldosterone activates $\mathrm{Na}+/ \mathrm{H}+$ exchange in vascular smooth muscle cells by nongenomic and genomic mechanisms. Kidney Int. 56,1400-1412.

39. Estrada,M., Liberona,J.L., Miranda,M., and Jaimovich,E., 2000. Aldosterone- and testosterone-mediated intracellular calcium response in skeletal muscle cell cultures. Am. J. Physiol. Endocrinol. Metab. 279,E132-E139.

40. Fardella,C.E., Mosso,L., Gomez-Sanchez,C., Cortes,P., Soto,J., Gomez,L., Pinto,M., Huete,A., Oestreicher,E., Foradori,A. et al, 2000. Primary Hyperaldosteronism in 
Essential Hypertensives: Prevalence, Biochemical Profile, and Molecular Biology. J Clin Endocrinol Metab 85,1863-1867.

41. Fiebeler,A., Schmidt,F., Muller,D.N., Park,J.K., Dechend,R., Bieringer,M., Shagdarsuren,E., Breu,V., Haller,H., and Luft,F.C., 2001. Mineralocorticoid receptor affects AP-1 and nuclear factor-kappab activation in angiotensin II-induced cardiac injury. Hypertension 37,787-793.

42. Fiebeler,A., Nussberger,J., Shagdarsuren,E., Rong,S., Hilfenhaus,G., Al Saadi,N., Dechend,R., Wellner,M., Meiners,S., Maser-Gluth,C. et al, 2005. Aldosterone Synthase Inhibitor Ameliorates Angiotensin II-Induced Organ Damage. Circulation 111,3087-3094.

43. Flamant,M., Tharaux,P.L., Placier,S., Henrion,D., Coffman,T., Chatziantoniou,C., and Dussaule,J.C., 2003. Epidermal growth factor receptor transactivation mediates the tonic and fibrogenic effects of endothelin in the aortic wall of transgenic mice. FASEB J 17,327-329.

44. Florian,J.A., Dorrance,A., Webb,R.C., and Watts,S.W., 2001. Mineralocorticoids upregulate arterial contraction to epidermal growth factor. Am J Physiol Regul Integr Comp Physiol JID - 100901230 281,R878-R886.

45. Francois,H., Placier,S., Flamant,M., Tharaux,P.L., Chansel,D., Dussaule,J.C., and Chatziantoniou,C., 2004. Prevention of renal vascular and glomerular fibrosis by epidermal growth factor receptor inhibition. FASEB J. 18,926-928.

46. Fujisawa,G., Okada,K., Muto,S., Fujita,N., Itabashi,N., Kusano,E., and Ishibashi,S., 2003. $\mathrm{Na} / \mathrm{H}$ exchange isoform 1 is involved in mineralocorticoid/salt-induced cardiac injury. Hypertension 41,493-498.

47. Fujita,M., Minamino,T., Asanuma,H., Sanada,S., Hirata,A., Wakeno,M., Myoishi,M., Okuda,H., Ogai,A., Okada,K.i. et al, 2005. Aldosterone Nongenomically Worsens Ischemia Via Protein Kinase C-Dependent Pathways in Hypoperfused Canine Hearts. Hypertension 46,113-117.

48. Ganong,W.F. and Mulrow,P.J., 1958. Rate of Change in Sodium and Potassium Excretion After Injection of Aldosterone Into the Aorta and Renal Artery of the Dog. Am J Physiol 195,337-342.

49. Gekle,M., Freudinger,R., Mildenberger,S., Schenk,K., Marschitz,I., and Schramek,H., 2001. Rapid activation of $\mathrm{Na}^{+} / \mathrm{H}^{+}$-exchange in MDCK-cells by aldosterone involves MAP-kinases ERK1/2. Pflügers Arch. 441,781-786.

50. Gekle,M., Freudinger,R., Mildenberger,S., and Silbernagl,S., 2002. Aldosterone interaction with epidermal growth factor receptor signaling in MDCK cells. Am J Physiol Renal Physiol 282,F669-F679.

51. Gekle,M., Golenhofen,N., Oberleithner,H., and Silbernagl,S., 1996. Rapid activation of $\mathrm{Na}^{+} / \mathrm{H}^{+}$-exchange by aldosterone in renal epithelial cells requires $\mathrm{Ca}^{2+}$ and stimulation of a plasma membrane proton conductance. Proc. Natl. Acad. Sci. USA 93,10500-10504. 
52. Gekle,M., Silbernagl,S., and Oberleithner,H., 1997. The mineralocorticoid aldosterone activates a proton conductance in cultured kidney cells. Am. J. Physiol. 273,C1673C1678.

53. Gekle,M., Mildenberger,S., Freudinger,R., and Grossmann,C., 2007. Altered collagen homeostasis in human aortic smooth muscle cells (HAoSMCs) induced by aldosterone. Pfluegers Archiv European Journal of Physiology 454,403-413.

54. Golestaneh,N., Klein,C., Valamanesh,F., Suarez,G., Agarwal,M.K., and Mirshahi,M., 2001. Mineralocorticoid Receptor-Mediated Signaling Regulates the lon Gated Sodium Channel in Vascular Endothelial Cells and Requires an Intact Cytoskeleton. Biochemical and Biophysical Research Communications 280,1300-1306.

55. Good,D.W., George,T., and Watts,B.A., 2002. Aldosterone inhibits $\mathrm{HCO}_{3}{ }^{-}$absorption via a nongenomic pathway in medullary thick ascending limb. Am. J. Physiol. 283,F699-F706.

56. Good,D.W., George,T., and Watts III,B.A., 2006. Nongenomic Regulation by Aldosterone of the Epithelial NHE3 Na+/H+ Exchanger. AJP - Cell Physiology 290, C757-C763.

57. Gros,R., Ding,Q., Armstrong,S., O'Neil,C., Pickering,J.G., and Feldman,R.D., 2007. Rapid effects of aldosterone on clonal human vascular smooth muscle cells. AJP Cell Physiology 292,C788-C794.

58. Grossmann,C., Benesic,A., Krug,A.W., Freudinger,R., Mildenberger,S., Gassner,B., and Gekle,M., 2005. Human mineralocorticoid receptor expression renders cells responsive for nongenotropic aldosterone actions. Mol. Endocrinol. 19,1697-1710.

59. Grossmann,C., Freudinger,R., Mildenberger,S., Husse,B., and Gekle,M., 2008. EF Domains Are Sufficient for Nongenomic Mineralocorticoid Receptor Actions. J. Biol. Chem. 283,7109-7116.

60. Grossmann,C., Krug,A.W., Freudinger,R., Mildenberger,S., Voelker,K., and Gekle,M., 2007. Aldosterone-induced EGFR expression: interaction between the human mineralocorticoid receptor and the human EGFR promoter. Am J Physiol Endocrinol Metab 292,E1790-E1800.

61. Gunaruwan,P., Schmitt,M., Sharman,J., Lee,L., Struthers,A., and Frenneaux,M., 2005. Effects of aldosterone on forearm vasculature in treated chronic heart failure. The American Journal of Cardiology 95,412-414.

62. Guo,X., Razandi,M., Pedram,A., Kassab,G., and Levin,E.R., 2005. Estrogen Induces Vascular Wall Dilation: Mediation through kinase signaling to nitric oxide and estrogen receptors alpha and beta. J. Biol. Chem. 280,19704-19710.

63. Harvey,B.J. and Higgins,M., 2000. Nongenomic effects of aldosterone on $\mathrm{Ca}^{2+}$ in $\mathrm{M}-1$ cortical collecting duct cells. Kidney Int. 57,1395-1403.

64. Harvey,B.J., Doolan,C.M., Condliffe,S.B., Renard,C., Alzamora,R., and Urbach,V., 2002. Non-genomic convergent and divergent signalling of rapid responses to aldosterone and estradiol in mammalian colon. Steroids 67,483-491. 
65. Haseroth,K., Gerdes,D., Berger,S., Feuring,M., Günther,A., Herbst,C., Christ,M., and Wehling,M., 1999. Rapid nongenomic effects of aldosterone in mineralocorticoidreceptor-knockout mice. Biochem. Biophys. Res. Commun. 266,257-261.

66. Hayashi,H., Kobara,M., Abe,M.K., Tanaka,N., Gouda,E., Toba,H., Yamada,H., Tatsumi,T., Nakata,T., and Matsubara,H., 2008. Aldosterone Nongenomically Produces NADPH Oxidase-Dependent Reactive Oxygen Species and Induces Myocyte Apoptosis. Hypertension Research 31,363-375.

67. Ishizawa,K., Izawa,Y., Ito,H., Miki,C., Miyata,K., Fujita,Y., Kanematsu,Y., Tsuchiya,K., Tamaki,T., Nishiyama,A. et al, 2005. Aldosterone stimulates vascular smooth muscle cell proliferation via big mitogen-activated protein kinase 1 activation. Hypertension 46,1046-1052.

68. Iwashima,F., Yoshimoto,T., Minami,I., Sakurada,M., Hirono,Y., and Hirata,Y., 2008. Aldosterone Induces Superoxide Generation via Rac1 Activation in Endothelial Cells. Endocrinology 149,1009-1014.

69. Jaffe,I.Z. and Mendelsohn,M.E., 2005. Angiotensin II and Aldosterone Regulate Gene Transcription Via Functional Mineralocortocoid Receptors in Human Coronary Artery Smooth Muscle Cells. Circ Res01.

70. Kagiyama,S., Qian,K., Kagiyama,T., and Phillips,M.I., 2003. Antisense to epidermal growth factor receptor prevents the development of left ventricular hypertrophy. Hypertension 41,824-829.

71. Kagiyama,S., Eguchi,S., Frank,G.D., Inagami,T., Zhang,Y.C., and Phillips,M.I., 2002. Angiotensin II-Induced Cardiac Hypertrophy and Hypertension Are Attenuated by Epidermal Growth Factor Receptor Antisense. Circulation 106,909-912.

72. Karst,H., Berger,S., Turiault,M., Tronche,F., and Schütz,G., 2005. Mineralocorticoid receptors are indispensable for nongenomic modulation of hippocampal glutamate transmission by corticosterone. Proc Natl Acad Sci U S A 102,19204-19207.

73. Khaksari,M., Rashidy-Pour,A., and Vafaei,A.A., 2007. Central mineralocorticoid receptors are indispensable for corticosterone-induced impairment of memory retrieval in rats. Neuroscience 149,729-738.

74. Klein,K. and Henk W, 1964. Klinisch-experimentelle Untersuchung über den Einfluss von Aldosteron auf Hämodynamik und Gerinnung. Z. Kreisl. Forsch. 52,40-53.

75. Kobayashi,N., Yoshida,K., Nakano,S., Ohno,T., Honda,T., Tsubokou,Y., and Matsuoka,H., 2006. Cardioprotective Mechanisms of Eplerenone on Cardiac Performance and Remodeling in Failing Rat Hearts. Hypertension 47,671-679.

76. Kolla,V. and Litwack,G., 2000. Transcriptional regulation of the human NA/K ATPase via the human mineralocorticoid receptor. Mol. Cell. Biochem. 204,35-40.

77. Kometiani,P., Li,J., Gnudi,L., Kahn,B.B., Askari,A., and Xie,Z., 1998. Multiple Signal Transduction Pathways Link Na+/K+-ATPase to Growth-related Genes in Cardiac Myocytes. The Roles of Ras and Mitogen-activated Protein Kinases. J. Biol. Chem. $273,15249-15256$. 
78. Korz,V. and Frey,J.U., 2003. Stress-Related Modulation of Hippocampal Long-Term Potentiation in Rats: Involvement of Adrenal Steroid Receptors. J. Neurosci. 23,72817287.

79. Krug,A.W., Schuster,C., Gassner,B., Freudinger,R., Mildenberger,S., Troppmair,J., and Gekle,M., 2002. Human EGF receptor 1 (HER1) expression renders $\mathrm{CHO}$ cells sensitive to alternative aldosterone signaling. J. Biol. Chem. 277,45892-45897.

80. Kuzkaya,N., Weissmann,N., Harrison,D.G., and Dikalov,S., 2003. Interactions of Peroxynitrite, Tetrahydrobiopterin, Ascorbic Acid, and Thiols: Implications for Uncoupling Endothelial Nitric-Oxide Syntase. J. Biol. Chem. 278,22546-22554.

81. Le Moellic,C., Ouvrard-Pascaud,A., Capurro,C., Cluzeaud,F., Fay,M., Jaisser,F., Farman,N., and Blot-Chabaud,M., 2004. Early nongenomic events in aldosterone action in renal collecting duct cells: PKCalpha activation, mineralocorticoid receptor phosphorylation, and cross-talk with the genomic response. J Am Soc. Nephrol. 15,1145-1160.

82. Leopold,J.A., Dam,A., Maron,B.A., Scribner,A.W., Liao,R., Handy,D.E., Stanton,R.C., Pitt,B., and Loscalzo,J., 2007. Aldosterone impairs vascular reactivity by decreasing glucose-6-phosphate dehydrogenase activity. Nat Med 13,189-197.

83. Liu,S.L., Schmuck,S., Chorazcyzewski,J.Z., Gros,R., and Feldman,R.D., 2003. Aldosterone Regulates Vascular Reactivity: Short-Term Effects Mediated by Phosphatidylinositol 3-Kinase-Dependent Nitric Oxide Synthase Activation. Circulation 108,2400-2406.

84. Maguire,D., MacNamara,B., Cuffe,J.E., Winter,D., Doolan,C.M., Urbach,V., O'Sullivan,G.C., and Harvey,B.J., 1999. Rapid responses to aldosterone in human distal colon. Steroids 64,51-63.

85. Malcher-Lopes,R., Di,S., Marcheselli,V.S., Weng,F.J., Stuart,C.T., Bazan,N.G., and Tasker,J.G., 2006. Opposing Crosstalk between Leptin and Glucocorticoids Rapidly Modulates Synaptic Excitation via Endocannabinoid Release. J. Neurosci. 26,66436650.

86. Markos,F., Healy, V., and Harvey,B.J., 2005. Aldosterone rapidly activates $\mathrm{Na}+/ \mathrm{H}+$ exchange in $\mathrm{M}-1$ cortical collecting duct cells via a PKC-MAPK pathway. Nephron Physiol 99,1-9.

87. Mazak,I., Fiebeler,A., Muller,D.N., Park,J.K., Shagdarsuren,E., Lindschau,C., Dechend,R., Viedt,C., Pilz,B., Haller,H. et al, 2004. Aldosterone Potentiates Angiotensin II-Induced Signaling in Vascular Smooth Muscle Cells. Circulation $109,2792-2800$.

88. McEneaney,V., Harvey,B.J., and Thomas,W., 2007. Aldosterone rapidly activates protein kinase $D$ via a mineralocorticoid receptor/EGFR trans-activation pathway in the M1 kidney CCD cell line. The Journal of Steroid Biochemistry and Molecular Biology 107,180-190. 
89. McEneaney,V., Harvey,B.J., and Thomas,W., 2008. Aldosterone Regulates Rapid Trafficking of Epithelial Sodium Channel Subunits in Renal Cortical Collecting Duct Cells via Protein Kinase D Activation. Molecular Endocrinology 22,881-892.

90. Michea,L., Delpiano,A.M., Hitschfeld,C., Lobos,L., Lavandero,S., and Marusic,E.T., 2005. Eplerenone Blocks Nongenomic Effects of Aldosterone on the $\mathrm{Na}+/ \mathrm{H}+$ Exchanger, Intracellular Ca2+ Levels, and Vasoconstriction in Mesenteric Resistance Vessels. Endocrinology 146,973-980.

91. Mihailidou,A.S., Buhagiar,K.A., and Rasmussen,H.H., 1998. $\mathrm{Na}^{+}$influx and $\mathrm{Na}^{+}-$ $\mathrm{K}^{+}$pump activation during short-term exposure of cardiac myocytes to aldosterone. Am. J. Physiol. 274,C175-C181.

92. Mihailidou,A.S., Bundgaard,H., Mardini,M., Hansen,P.S., Kjeldsen,K., and Rasmussen,H.H., 2000. Hyperaldosteronemia in rabbits inhibits the cardiac sarcolemmal $\mathrm{Na}^{+}-\mathrm{K}^{+}$pump. Circ. Res. 86,37-42.

93. Mihailidou,A.S. and Funder,J.W., 2005. Nongenomic effects of mineralocorticoid receptor activation in the cardiovascular system. Steroids 70,347-351.

94. Mihailidou,A.S., Mardini,M., and Funder,J.W., 2004a. Rapid, nongenomic effects of aldosterone in the heart mediated by epsilon protein kinase $\mathrm{C}$. Endocrinology 145,773-780.

95. Mihailidou,A.S., 2006. Nongenomic actions of aldosterone: Physiological or pathophysiological role? Steroids 71,277-280.

96. Mihailidou,A.S., Mardini,M., and Funder,J.W., 2004b. Rapid, Nongenomic Effects of Aldosterone in the Heart Mediated by \{epsilon\} Protein Kinase C. Endocrinology 145,773-780.

97. Mihailidou,A.S., Mardini,M., Funder,J.W., and Raison,M., 2002. Mineralocorticoid and Angiotensin Receptor Antagonism During Hyperaldosteronemia. Hypertension 40,124-129.

98. Min,L.J., Mogi,M., Li,J.M., Iwanami,J., Iwai,M., and Horiuchi,M., 2005. Aldosterone and Angiotensin II Synergistically Induce Mitogenic Response in Vascular Smooth Muscle Cells. Circ Res 97,434-442.

99. Miyata $\mathrm{Y}$, Muto S, and Kusano E, 2005. Mechanisms for nongenomic and genomic effects of aldosterone on $\mathrm{Na}+/ \mathrm{H}+$ exchange in vascular smooth muscle cells. J Hypertens 12,2237-2250.

100. Miyata,K., Rahman,M., Shokoji,T., Nagai,Y., Zhang,G.X., Sun,G.P., Kimura,S., Yukimura,T., Kiyomoto,H., Kohno,M. et al, 2005. Aldosterone Stimulates Reactive Oxygen Species Production through Activation of NADPH Oxidase in Rat Mesangial Cells. Journal of the American Society of Nephrology 16,2906-2912.

101. Montezano,A.C., Callera,G.E., Yogi,A., He,Y., Tostes,R.C., He,G., Schiffrin,E.L., and Touyz,R.M., 2008. Aldosterone and Angiotensin II Synergistically Stimulate Migration in Vascular Smooth Muscle Cells Through c-Src-Regulated Redox-Sensitive RhoA Pathways. Arterioscler Thromb Vasc Biol 28,1511-1518. 
102. Moura,A.M. and Worcel,M., 1984. Direct action of aldosterone on transmembrane 22Na efflux from arterial smooth muscle. Rapid and delayed effects. Hypertension $6,425-430$.

103. Mutoh,A., Isshiki,M., and Fujita,T., 2008. Aldosterone enhances ligand-stimulated nitric oxide production in endothelial cells. Hypertens Res. 31,1811-1820.

104. Nagata,D., Takahashi,M., Sawai,K., Tagami,T., Usui,T., Shimatsu,A., Hirata,Y., and Naruse,M., 2006. Molecular Mechanism of the Inhibitory Effect of Aldosterone on Endothelial NO Synthase Activity. Hypertension 48,165-171.

105. Nakano,S., Kobayashi,N., Yoshida,K., Ohno,T., and Matsuoka,H., 2005. Cardioprotective Mechanisms of Spironolactone Associated with the AngiotensinConverting Enzyme/Epidermal Growth Factor Receptor/Extracellular SignalRegulated Kinases, NAD(P)H Oxidase/Lectin-Like Oxidized Low-Density Lipoprotein Receptor-1, and Rho-Kinase Pathways in Aldosterone/Salt-Induced Hypertensive Rats. Hypertens Res. 28,925-936.

106. Nietlispach,F., Julius,B., Schindler,R., Bernheim,A., Binkert,C., Kiowski,W., and Brunner-La Rocca,H.P., 2007. Influence of Acute and Chronic Mineralocorticoid Excess on Endothelial Function in Healthy Men. Hypertension 50,82-88.

107. Oberleithner,H., Weigt,M., Westphale,H.-J., and Wang,W., 1987. Aldosterone activates $\mathrm{Na}^{+} / \mathrm{H}^{+}$exchange and raises cytoplasmic $\mathrm{pH}$ in target cells of the amphibian kidney. Proc. Natl. Acad. Sci. USA 84,1464-1468.

108. Oitzl,M., Flyvbjerg,A., and de Kloet,E.R., 1994. The effect of corticosterone on reactivity to spatial novelty is mediated by central mineralocorticosteroid receptors. Eur J Neurosci. 6,1072-1079.

109. Olijslagers,J., de Kloet,E.R., Elgersma,Y., van Woerden,G., Joels,M., and Karst,H., 2008. Rapid changes in hippocampal CA1 pyramidal cell function via pre- as well as postsynaptic membrane mineralocorticoid receptors. Eur J Neurosci. 27,2542-2550.

110. Orshal,J.M. and Khalil,R.A., 2004. Gender, sex hormones, and vascular tone. AJP Regulatory, Integrative and Comparative Physiology 286,R233-R249.

111. Ouvrard-Pascaud,A., Sainte-Marie,Y., Benitah,J.P., Perrier,R., Soukaseum,C., Cat,A.N.D., Royer,A., Le Quang,K., Charpentier,F., Demolombe,S. et al, 2005. Conditional Mineralocorticoid Receptor Expression in the Heart Leads to LifeThreatening Arrhythmias. Circulation 111,3025-3033.

112. Pitt,B., Remme,W., Zannad,F., Neaton,J., Martinez,F., Roniker,B., Bittman,R., Hurley,S., Kleiman,J., and Gatlin,M., 2003a. Eplerenone, a selective aldosterone blocker, in patients with left ventricular dysfunction after myocardial infarction. $\mathrm{N}$ Engl J Med 348,1309-1321.

113. Pitt,B., Zannad,F., Remme,W.J., Cody,R., Castaigne,A., Perez,A., Palensky,J., and Wittes,J., 1999. The effect of spironolactone on morbidity and mortality in patients with severe heart failure. Randomized Aldactone Evaluation Study Investigators. N Engl J Med 341,709-717. 
114. Pitt,B., Reichek,N., Willenbrock,R., Zannad,F., Phillips,R.A., Roniker,B., Kleiman,J., Krause,S., Burns,D., and Williams,G.H., 2003b. Effects of Eplerenone, Enalapril, and Eplerenone/Enalapril in Patients With Essential Hypertension and Left Ventricular Hypertrophy: The 4E-Left Ventricular Hypertrophy Study. Circulation 108,1831-1838.

115. Pu,Z., Krugers,H., and Joels,M., 2007. Corticosterone time-dependently modulates beta-adrenergic effects on long-term potentiation in the hippocampal dentate gyrus. Learn Mem. 14,359-367.

116. Qin,W., Rudolph,A.E., Bond,B.R., Rocha,R., Blomme,E.A.G., Goellner,J.J., Funder,J.W., and McMahon,E.G., 2003. Transgenic Model of Aldosterone-Driven Cardiac Hypertrophy and Heart Failure. Circ Res 93,69-76.

117. Rocha,R., Rudolph,A.E., Frierdich,G.E., Nachowiak,D.A., Kekec,B.K., Blomme,E.A., McMahon,E.G., and Delyani,J.A., 2002. Aldosterone induces a vascular inflammatory phenotype in the rat heart. Am J Physiol Heart Circ. Physiol 283,H1802-H1810.

118. Romagni,P., Rossi,F., Guerrini,L., Quirini,C., and Santiemma,V., 2003. Aldosterone induces contraction of the resistance arteries in man. Atherosclerosis 166,345-349.

119. Rossi,G.P., Bernini,G., Caliumi,C., Desideri,G., Fabris,B., Ferri,C., Ganzaroli,C., Giacchetti,G., Letizia,C., Maccario,M. et al, 2006. A Prospective Study of the Prevalence of Primary Aldosteronism in 1,125 Hypertensive Patients. Journal of the American College of Cardiology 48,2293-2300.

120. Rossol-Haseroth,K., Zhou,Q., Braun,S., Boldyreff,B., Falkenstein,E., Wehling,M., and Losel,R.M., 2004. Mineralocorticoid receptor antagonists do not block rapid ERK activation by aldosterone. Biochem. Biophys. Res Commun. 318,281-288.

121. Rude,M.K., Duhaney,T.A., Kuster,G.M., Judge,S., Heo,J., Colucci,W.S., Siwik,D.A., and Sam,F., 2005. Aldosterone Stimulates Matrix Metalloproteinases and Reactive Oxygen Species in Adult Rat Ventricular Cardiomyocytes. Hypertension 46,555-561.

122. Schmidt,B.M., Sammer,U., Fleischmann,I., Schlaich,M., Delles,C., and Schmieder,R.E., 2006. Rapid nongenomic effects of aldosterone on the renal vasculature in humans. Hypertension 47,650-655.

123. Schmidt,B.M.W., Georgens,A.C., Martin,N., Tillmann,H.-C., Feuring,M., Christ,M., and Wehling,M., 2001. Interaction of rapid nongenomic cardiovascular aldosterone effects with the adrenergic system. J. Clin. Endocrinol. Metab. 86,761-767.

124. Schmidt,B.M.W., Montealegre,A., Janson,C.P., Martin,N., Stein-Kemmesies,C., Scherhag,A., Feuring,M., Christ,M., and Wehling,M., 1999. Short term cardiovascular effects of aldosterone in healthy male volunteers. J. Clin. Endocrinol. Metab. 84,35283533.

125. Schmidt,B.M.W., Oehmer,S., Delles,C., Bratke,R., Schneider,M.P., Klingbeil,A., Fleischmann,E.H., and Schmieder,R.E., 2003. Rapid Nongenomic Effects of Aldosterone on Human Forearm Vasculature. Hypertension 42,156-160. 
126. Schneider,M., Ulsenheimer,A., Christ,M., and Wehling,M., 1997a. Nongenomic effects of aldosterone on intracellular calcium in porcine endothelial cells. Am J Physiol Endocrinol Metab 272,E616-E620.

127. Schneider,S.W., Yano,Y., Sumpio,B.E., Jena,B.P., Geibel,J.P., Gekle,M., and Oberleithner,H., 1997b. Rapid aldosterone-induced cell volume increase of endothelial cells measured by the atomic force microscope. Cell. Biol. Int. 21,759768.

128. Sheader,E.A., Wargent,E.T., Ashton,N., and Balment,R.J., 2002. Rapid stimulation of cyclic AMP production by aldosterone in rat inner medullary collecting ducts. J. Endocrin. 175,343-347.

129. Simpson,S., Tait,J., Wettstein,A., Neher,R., von Euw,J., Schindler,O., and Reichenstein,T., 1954. Constitution of aldosterone, a new mineralocorticoid. Experientia 10,132-133.

130. Skott,O., Uhrenholt,T.R., Schjerning,J., Hansen,P.B.L., Rasmussen,L.E., and Jensen,B.L., 2006. Rapid actions of aldosterone in vascular health and disease-friend or foe? Pharmacology \& Therapeutics 111,495-507.

131. Spach,C. and Streeten,D.H., 1964. Retardation of sodium exchange in dog erythrocytes by physiological concentrations of aldosterone, in vitro. J Clin. Invest 43,217-227.

132. Stockand,J.D. and Meszaros,J.G., 2003. Aldosterone stimulates proliferation of cardiac fibroblasts by activating Ki-RasA and MAPK1/2 signaling. Am J Physiol Heart Circ Physiol 284,H176-H184.

133. Terada,Y., Kobayashi,T., Kuwana,H., Tanaka,H., Inoshita,S., Kuwahara,M., and Sasaki,S., 2005. Aldosterone Stimulates Proliferation of Mesangial Cells by Activating Mitogen-Activated Protein Kinase 1/2, Cyclin D1, and Cyclin A. Journal of the American Society of Nephrology 16,2296-2305.

134. Terzi,F., Burtin,M., Hekmati,M., Federici,P., Grimber,G., Briand,P., and Friedlander,G., 2000. Targeted expression of a dominant-negative EGF-R in the kidney reduces tubulo-interstitial lesions after renal injury. J Clin Invest 106,225-234.

135. Uhrenholt,T.R., Schjerning,J., Hansen,P.B., Norregaard,R., Jensen,B.L., Sorensen,G.L., and Skott,O., 2003. Rapid Inhibition of Vasoconstriction in Renal Afferent Arterioles by Aldosterone. Circ Res 93,1258-1266.

136. Ullian,M.E., Walsh,L.G., and Morinelli,T.A., 1996. Potentiation of angiotensin II action by corticosteroids in vascular tissue. Cardiovascular Research 32,266-273.

137. Virdis,A., Neves,M.F., Amiri,F., Viel,E., Touyz,R.M., and Schiffrin,E.L., 2002. Spironolactone improves angiotensin-induced vascular changes and oxidative stress. Hypertension 40,504-510.

138. Watts,B.A., III, George,T., and Good,D.W., 2006. Aldosterone inhibits apical NHE3 and $\mathrm{HCO} 3-$ absorption via a nongenomic ERK-dependent pathway in medullary thick ascending limb. AJP - Renal Physiology 291,F1005-F1013. 
139. Wehling,M., Bauer,M.M., Ulsenheimer,A., Schneider,M., Neylon,C.B., and Christ,M., 1996. Nongenomic effects of aldosterone on intracellular $\mathrm{pH}$ in vascular smooth muscle cells. Biochem. Biophys. Res. Commun. 223,181-186.

140. Wehling,M., Käsmayr,J., and Theisen,K., 1989a. Fast effects of aldosterone on electrolytes in human lymphocytes are mediated by the sodium-proton-exchanger of the cell membrane. Biochem. Biophys. Res. Commun. 164,961-967.

141. Wehling,M., Käsmayr,J., and Theisen,K., 1990. Aldosterone influences free intracellular calcium in human mononuclear leukocytes in vitro. Cell Calcium 11,565571.

142. Wehling,M., Kuhls,S., and Armanini,D., 1989b. Volume regulation of human lymphocytes by aldosterone in isotonic media. Am. J. Physiol. 257,E170-E174.

143. Wehling,M., Neylon,C.B., Fullerton,M., Bobik,A., and Funder,J.W., 1995. Nongenomic effects of aldosterone on intracellular $\mathrm{Ca}^{2+}$ in vascular smooth muscle cells. Circ. Res. 76,973-979.

144. Wehling,M., Spes,C.H., Win,N., Janson,C.P., Schmidt,B.M.W., Theisen,K., and Christ,M., 1998. Rapid cardiovascular action of aldosterone in man. J. Clin. Endocrinol. Metab. 83,3517-3522.

145. Wehling,M., Ulsenheimer,A., Schneider,M., Neylon,C., and Christ,M., 1994. Rapid effects of aldosterone on free intracellular calcium in vascular smooth muscle and endothelial cells: subcellular localization of calcium elevations by single cell imaging. Biochem. Biophys. Res. Commun. 204,475-481.

146. Winter,C., Schulz,N., Giebisch,G., Geibel,J.P., and Wagner,C.A., 2004. Nongenomic stimulation of vacuolar $\mathrm{H}+-$ ATPases in intercalated renal tubule cells by aldosterone. Proceedings of the National Academy of Sciences 101,2636-2641.

147. Xiao,F., Puddefoot,J., and Vinson,G.P., 2000. Aldosterone mediates angiotensin IIstimulated rat vascular smooth muscle cell proliferation. J Endocrinol 165,533-536.

148. Xiao,F., Puddefoot,J.R., Barker,S., and Vinson,G.P., 2004. Mechanism for Aldosterone Potentiation of Angiotensin II-Stimulated Rat Arterial Smooth Muscle Cell Proliferation. Hypertension 44,340-345.

149. Young,M. and Funder,J., 2003. Mineralocorticoid Action and Sodium-Hydrogen Exchange: Studies in Experimental Cardiac Fibrosis. Endocrinology 144,3848-3851.

150. Zhai,P., Galeotti,J., Liu,J., Holle,E., Yu,X., Wagner,T., and Sadoshima,J., 2006. An Angiotensin II Type 1 Receptor Mutant Lacking Epidermal Growth Factor Receptor Transactivation Does Not Induce Angiotensin II-Mediated Cardiac Hypertrophy. Circ Res 99,528-536.

151. Zhang,A., Jia,Z., Guo,X., and Yang,T., 2007. Aldosterone induces epithelialmesenchymal transition via ROS of mitochondrial origin. AJP - Renal Physiology 293,F723-F731. 
152. Zhu,Y., Rice,C.D., Pang,Y., Pace,M., and Thomas,P., 2003. Cloning, expression, and characterization of a membrane progestin receptor and evidence it is an intermediary in meiotic maturation of fish oocytes. Proc Natl Acad Sci U S A 100,2231-2236. 
Tab. 1 Molecules involved in nongenomic aldosterone signaling

\begin{tabular}{|c|c|c|}
\hline CAMP & $\begin{array}{l}\text { porcine VSMC } \\
\text { Inner medullary collecting duct }\end{array}$ & $\begin{array}{l}\text { (Christ et al., 1999) } \\
\text { (Sheader et al., 2002) }\end{array}$ \\
\hline IP3 & $\begin{array}{l}\text { HML } \\
\text { VSMC } \\
\text { A6 cells } \\
\text { skeletal muscle cells }\end{array}$ & $\begin{array}{l}\text { (Christ et al., 1993) } \\
\text { (Christ et al., 1995) } \\
\text { (Blazer-Yost et al., 1999) } \\
\text { (Estrada et al., 2000) }\end{array}$ \\
\hline $\mathrm{Ca}^{2+}$ & $\begin{array}{l}\text { VSMC, EC } \\
\text { VSMC (rat and rabbit aortic) } \\
\text { T84 colonic epithelial cells } \\
\text { porcine EC } \\
\text { skin fibroblasts from MR-/- mice } \\
\text { skeletal muscle cells } \\
\text { M-1 cells } \\
\text { small resistance mesenteric vessels } \\
\text { HEK (MR) cells }\end{array}$ & $\begin{array}{l}\text { (Wehling et al., 1994) } \\
\text { (Wehling et al., 1995) } \\
\text { (Doolan et al., 1996) } \\
\text { (Schneider et al., 1997) } \\
\text { (Haseroth et al., 1999) } \\
\text { (Estrada et al., 2000) } \\
\text { (Harvey et al., 2000) } \\
\text { (Michea et al., 2005) } \\
\text { (Grossmann et al., 2005) }\end{array}$ \\
\hline PKC & $\begin{array}{l}\text { rat VSMC } \\
\text { MDCK } \\
\text { rat VSMC } \\
\text { M1 cells } \\
\text { rabbit cardiomyocytes } \\
\text { rabbit preglomerular afferent arteriole } \\
\text { OMCD } \\
\text { coronary arteries (LAD) dogs } \\
\text { adult rat ventricular cardiomyocytes } \\
\text { human trabeculae (heart) } \\
\text { in vitro } \\
\text { crypt cells from human sigmoid colon }\end{array}$ & $\begin{array}{l}\text { (Estrada et al., 2000) } \\
\text { (Gekle et al., 1997) } \\
\text { (Ebata et al., 1999) } \\
\text { (Harvey et al., 2000) } \\
\text { (Mihailidou et al., 2004a) } \\
\text { (Arima et al., 2004) } \\
\text { (Winter et al., 2004) } \\
\text { (Fujita et al., 2005) } \\
\text { (Rude et al., 2005) } \\
\text { (Chai et al., 2005) } \\
\text { (Alzamora et al., 2007) } \\
\text { (Bowley et al., 2007) }\end{array}$ \\
\hline ERK1/2 & $\begin{array}{l}\text { MDCK C11 } \\
\text { M1 cells } \\
\text { HEK, CHO cells: heterolog system } \\
\text { aortic VSMC (rat) } \\
\text { aortic VSMC (rat) } \\
\text { adult rat ventricular cardiomyocytes } \\
\text { rat aortic smooth muscle cells } \\
\text { human coronary arteries } \\
\text { M1 cells } \\
\text { rat MTAL } \\
\text { bovine aortic endothelial cells, rat VSMC } \\
\text { ERK phosporylation } \\
\text { M1 cells } \\
\text { rat mesangial cells } \\
\text { HK-2 cells }\end{array}$ & $\begin{array}{l}\text { (Gekle et al., 2002) } \\
\text { (Rossol-Haseroth et al., 2004) } \\
\text { (Grossmann et al., 2005) } \\
\text { (Mazak et al., 2004) } \\
\text { (Min et al., 2005) } \\
\text { (Rude et al., 2005) } \\
\text { (Ishizawa et al., 2005) } \\
\text { (Chai et al., 2005) } \\
\text { (McEneaney et al., 2007) } \\
\text { (Watts, III et al., 2006) } \\
\text { (Liu et al., 2003) } \\
\text { (Kobayashi et al., 2006) } \\
\text { (Markos et al., 2005) } \\
\text { (Terada et al., 2005) } \\
\text { (Zhang et al., 2007) }\end{array}$ \\
\hline PI3K & $\begin{array}{l}\text { small mesenteric resistance vessels rat } \\
\text { human VSMC } \\
\text { rabbit renal afferent arteriole } \\
\text { bovine aortic endothelial cells } \\
\text { rat left ventricle Heart } \\
\text { bovine aortic EC }\end{array}$ & $\begin{array}{l}\text { (Michea et al., 2005) } \\
\text { (Gros et al., 2007) } \\
\text { (Uhrenholt et al., 2003) } \\
\text { (Liu et al., 2003) } \\
\text { (Kobayashi et al., 2006) } \\
\text { (Mutoh et al., 2008) }\end{array}$ \\
\hline C-src & $\begin{array}{l}\text { M1 cells } \\
\text { rat VSMC } \\
\text { rat VSMC (SHR) } \\
\text { rat VSMC } \\
\text { HEK (MR) cells }\end{array}$ & $\begin{array}{l}\text { (McEneaney et al., 2007) } \\
\text { (Callera et al., 2005b) } \\
\text { (Callera et al., 2005a) } \\
\text { (Montezano et al., 2008) } \\
\text { (Grossmann et al., 2005) }\end{array}$ \\
\hline interaction angll & $\begin{array}{l}\text { rat aortic VSMC } \\
\text { rat aortic VSMC } \\
\text { human coronary arteries } \\
\text { rat VSMC } \\
\text { human heart trabecula } \\
\text { human coronary artery smooth muscle cells } \\
\text { dTGR rats, left ventricle } \\
\text { dTGR rats, heart kidney } \\
\text { rat mesenteric small arteries, aortic segments } \\
\text { MR overexpression in cardiomyocytes (mice) }\end{array}$ & $\begin{array}{l}\text { (Mazak et al., 2004) } \\
\text { (Min et al., 2005) } \\
\text { (Chai et al., 2005) } \\
\text { (Montezano et al., 2008) } \\
\text { (Chai et al., 2005) } \\
\text { (Jaffe et al., 2005) } \\
\text { (Fiebeler et al., 2001) } \\
\text { (Fiebeler et al., 2005) } \\
\text { (Virdis et al., 2002) } \\
\text { (Di Zhang et al., 2008) }\end{array}$ \\
\hline interaction EGFR & $\begin{array}{l}\text { MDCKs-C11 cells } \\
\text { rat VSMC } \\
\text { M11 cells } \\
\text { HEK-MR, CHO-MR cells } \\
\text { rat aortic VSMC }\end{array}$ & $\begin{array}{l}\text { (Gekle et al., 2002) } \\
\text { (Mazak et al., 2004) } \\
\text { (McEneaney et al., 2007) } \\
\text { (Grossmann et al., 2005) } \\
\text { (Min et al., 2005) }\end{array}$ \\
\hline $\begin{array}{l}\text { NADPH oxidase / } \\
\text { ROS }\end{array}$ & $\begin{array}{l}\text { RAEC } \\
\text { rat mesangial cells } \\
\text { neonatal rat cardiomyocytes } \\
\text { rat VSMC } \\
\text { adult rat ventricular myocytes } \\
\text { rat aorta } \\
\text { rat VSMC } \\
\text { HK-2 cells }\end{array}$ & $\begin{array}{l}\text { (Iwashima et al., 2008) } \\
\text { (Miyata et al., 2005) } \\
\text { (Hayashi et al., 2008) } \\
\text { (Montezano et al., 2008) } \\
\text { (Rude et al., 2005) } \\
\text { (Virdis et al., 2002) } \\
\text { (Mazak et al., 2004) } \\
\text { (Zhang et al., 2007) } \\
\end{array}$ \\
\hline NOS & $\begin{array}{l}\text { HUVEC } \\
\text { bovine aortic EC } \\
\text { rabbit renal afferent arteriole } \\
\text { bovine aortic EC } \\
\text { rabbit afferent arteriole kidney } \\
\text { rat myocardial slices }\end{array}$ & $\begin{array}{l}\text { (Nagata et al., 2006) } \\
\text { (Mutoh et al., 2008) } \\
\text { (Uhrenholt et al., 2003) } \\
\text { (Liu et al., 2003) } \\
\text { (Arima et al., 2004) } \\
\text { (Kobayashi et al., 2006) }\end{array}$ \\
\hline NHE & $\begin{array}{l}\text { giant cells of distal nephron of frog } \\
\text { MDCK } \\
\text { small resistance mesenteric vessels } \\
\text { rat VSMC } \\
\text { VSMC } \\
\text { MTAL } \\
\text { M1 cells } \\
\text { Chorionic / radial uterine arteries } \\
\text { HML }\end{array}$ & $\begin{array}{l}\text { (Oberleithner et al., 1987) } \\
\text { (Gekle et al., 1996) } \\
\text { (Chai et al., 2005) } \\
\text { (Ebata et al., 1999) } \\
\text { (Miyata Y et al., 2005) } \\
\text { (Good et al., 2006) } \\
\text { (Markos et al., 2005) } \\
\text { (Alzamora et al., 2000) } \\
\text { (Wehling et al., 1989) }\end{array}$ \\
\hline
\end{tabular}


Tab. 2 Nongenomic aldosterone effects in cardiomyocytes and vessels

\begin{tabular}{|c|c|c|}
\hline cardiomyocytes & & $\begin{array}{l}\text { (Mihailidou et al., 1998) } \\
\text { (Mihailidou et al., 2000) } \\
\text { (Mihailidou et al., 2004b) } \\
\text { (Barbato et al., 2002) } \\
\text { (Chai et al., 2005) } \\
\text { (Hayashi et al., 2008) }\end{array}$ \\
\hline $\begin{array}{c}\text { vasculature } \\
\text { human volunteers / patients }\end{array}$ & & $\begin{array}{l}\text { (Nietlispach et al., 2007) } \\
\text { (Klein et al., 1964) } \\
\text { (Schmidt et al., 2001) } \\
\text { (Romagni et al., 2003) } \\
\text { (Schmidt et al., 2003) } \\
\text { (Schmidt et al., 2006) } \\
\text { (Gunaruwan et al., 2005) } \\
\text { (Schmidt et al., 1999) } \\
\text { (Wehling et al., 1998) }\end{array}$ \\
\hline \multirow{2}{*}{$\begin{array}{c}\text { vasculature } \\
\text { experimental data }\end{array}$} & vasodilation & $\begin{array}{l}\text { (Uhrenholt et al., 2003) } \\
\text { (Liu et al., 2003) }\end{array}$ \\
\hline & vasoconstriction & $\begin{array}{l}\text { (Arima et al., 2003) } \\
\text { (Chai et al., 2005) }\end{array}$ \\
\hline
\end{tabular}


Fig. 1

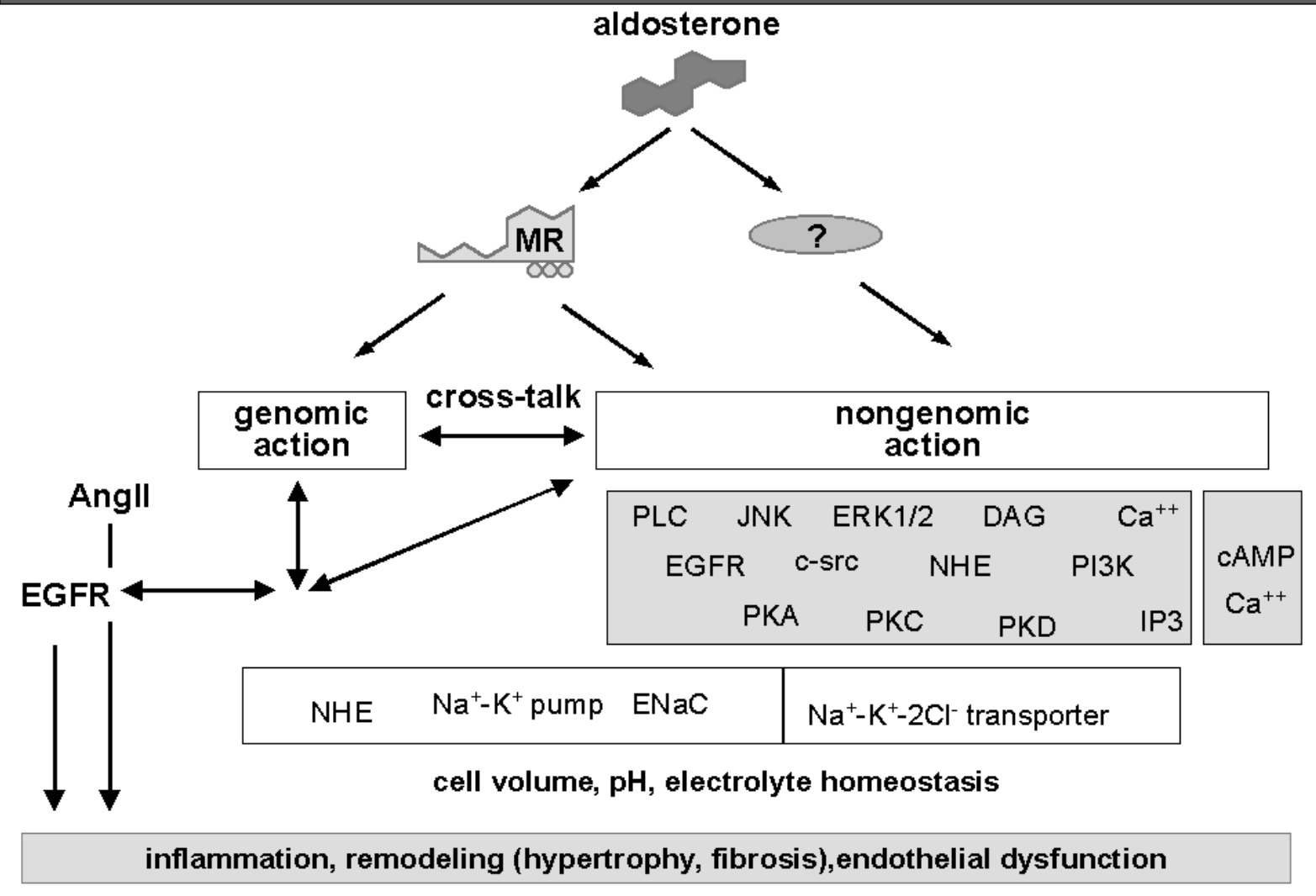

